\title{
The New Social Question: Rethinking the Welfare State, by Pierre Rosanvallon, translated by Barbara Harshav ; with a foreword by Nathan Glazer. Princeton, NJ: Princeton University Press, 2000, xii, 139 pp.
}

\author{
Reviewed by David Bartram, Department of Sociology, Colorado College, Colorado \\ Springs, CO.
}

Pierre Rosanvallon contends that the welfare state needs rethinking because of a "philosophical crisis" that has two principal manifestations: traditional modes of solidarity underpinning the welfare state are disintegrating, and the framework of "social rights" no longer suffices to address problems of long-term social exclusion (unemployment, in particular). Rosanvallon, Director of France's l'Ecole des Hautes Études en Siences Sociales, originally published this book in French in 1995. The English translation, just now available, offers some intriguing ideas, but it demands a real effort from the reader to overcome obstacles of presentation and clarity.

The book's first chapter ("Decline of the Insurance Society") makes a relatively compelling argument concerning the first aspect of the crisis. Rosanvallon begins by noting that the traditional "insurance" mode of social policy depends on a Rawlsian generalized ignorance concerning risk factors leading to conditions that require aid. When a population imagines itself as homogenous, such that no one knows who is likely to get sick, experience unemployment, or become poor, then individuals are willing to contribute to an insurance scheme from which he or she is just as likely to benefit as anyone else. Given a vastly increased knowledge concerning risk factors for, say, disease (including genetic factors), however, those who lack such factors begin to wonder why they should contribute to a scheme whose benefits will almost surely go disproportionately to some sub-group whose members can be identified in advance.

The argument works best in relation to insurance models for organizing health care, for obvious reasons that Rosanvallon explores effectively. There is also a cogent discussion of increasingly prevalent demands for "individual responsibility" concerning behaviors that lead to conditions that place heavy demands on public expenditures, e.g. smoking and alcohol abuse: "The smoker will soon be required to choose between his vice and the right to equal access to care, and the alcoholic will be threatened with [demand for] payment of social surcharges" (p. 21). Those who do not smoke or abuse alcohol believe that those who do so choose the behaviors that impose costs on others - much as some people believe that many welfare recipients choose not to work because the availability of government aid simply makes it possible not to do so.

To overcome the threats to solidarity that arise from such perceptions, Rosanvallon argues, a new form of solidarity is required - one that seeks explicitly to compensate for inequalities rooted in inherited or objective factors rather than to smooth out temporary disparities in income. In practical terms, this new solidarity relies on a new funding mechanism whose nature is not yet clear, except that it must be something other than insurance "premiums" and the traditional income tax.

The framework of social rights - the second aspect of the crisis - has become inadequate, Rosanvallon argues, insofar as it remains rooted in 17th century liberal individualism, where freedom and autonomy are the hegemonic values. Current economic conditions, under which large population segments remain unemployed for extended periods, expose the limits of such values and of a welfare state beholden to them. The problem itself is familiar, especially in Europe: as the ranks of the excluded - and the payments they expect to receive - grow, so too do the taxes necessary to fund such payments. Higher taxes mean decreased demand for labor - and so we arrive at "a pernicious spiral we might call a social deflation: an increasing quantity of nonworking people are cared for by a decreasing number of workers" (p. 57). Increasing economic globalization only exacerbates the difficulty.

The dilemma can be overcome, Rosanvallon contends, only by employing a framework of inclusion, as against the "passive welfare state" model of providing compensation for exclusion. A universal allowance - as well as the extension of disability payments to the category of the "socially disabled," i.e., those who remained unemployed after their unemployment benefits expired - only dodges the problem and thereby exacerbates it. Inclusion, on the other hand, begins with the possibility of using public funds "to pay workers rather than to indemnify the unemployed" (p. 57). In practical terms, inclusion in the American context means workfare, and in France it is embodied in the somewhat broader program of the "minimum subsistence allowance" (RMI). "In both cases, social rights are reinterpreted as a contract articulating rights and obligations" (p. 87). In other words, according to Rosanvallon, an individual's right to inclusion demands both that the individual make himself or 
Reviews

herself useful to society and that the society recognize and respond to the individual's own desire for social utility in particular by providing jobs or some equivalent.

This notion of mutual obligation has always looked good on paper. Many American readers, however, will remain quite unpersuaded by the claim that workfare in the US enhances inclusion for welfare recipients.

Rosanvallon does not consider critiques (e.g. Piven and Cloward 1993) arguing that the function of workfare is primarily punitive: an effort to restore labor discipline by showing workers the fate that awaits them should they demand too much of their employers or the state. This argument is reinforced by anecdotes describing how workfare participants in New York have been made to rake leaves, only to watch a supervisor empty the bags and insist that the raking begin again (Finder 1998). The French RMI program, however, may offer more compelling testimony to the potential for a social policy founded on expectations of mutual obligation.

The book's aspirations are also hindered by an almost total blindness to issues of gender. Rosanvallon overlooks the fact that the problem of welfare, in the US, at least, is largely the problem of single mothers who cannot get paid jobs that allow them to meet their obligations to their children - in a word, to survive. This problem will not be solved by asserting a societal obligation to guarantee the mere availability of jobs, which is what the second half of Rosanvallon's argument reduces to in practical terms. Achieving inclusion for poor single mothers would seem to require a more ramified apparatus that allows them to reconcile work and motherhood (including heavily subsidized and reliable day care). Even that formulation, however, is inadequate when one accepts the argument (e.g. Mink 1998) that motherhood is work and deserves to be supported as such. Here is the real conundrum for those concerned with reconnecting the economic and the social, as Rosanvallon puts it. Finally, there are some patently offensive references to women: on p. 97, for example, we encounter the phrase "sluggish...elderly women," for which there is no elaboration.

Another disappointing aspect of the book is its frequent failure to flesh out arguments with examples. For example, in Chapter 2 ("Remaking a Nation"), Rosanvallon argues that "European societies today are characterized by contradiction. On the one hand, they need to remake the nation, to turn inward to reinforce the bonds of solidarity; on the other hand, they must open themselves outward economically" (p. 38). While the second half of that formulation is fairly clear in its implicit reference to economic globalization, the first half needs elaboration: it is simply not very clear what "turning inward" means. In other instances, the examples provided seem trivial with respect to the point under consideration. To support the claim that "the notion of justice or equity [increasingly] prevails over that of interest" (p. 33) in contemporary conflicts, for example, we are told that French truck drivers in 1992 "protest[ed] the injustice of granting the same number of 'points' on drivers' licenses to professionals driving one hundred thousand kilometers a year and to amateur drivers" (p. 33). (We do not learn whether the protest was successful.)

Surprisingly, there is no discussion of how immigrants to France have affected the welfare state and, in particular, the solidarity that Rosanvallon considers necessary to sustain it under conditions of increased awareness concerning risks. The issue is perhaps the object of the vague reference to "turning inward" (p. 38) discussed above; but, again, it is not entirely clear what this phrase means. For the purposes of reinforcing solidarity, are French citizens of foreign origin to be considered outsiders? Even if the proposed solidarity is expansive, such that only non-citizen permanent residents are to be excluded from the French welfare state, the implicit attitude towards immigrants raises more questions than it answers. But that statement perhaps depends on an over-interpretation of a few comments made almost in passing.

Perhaps the most puzzling aspect of the book is its renunciation of a basic competence of social science. Chapter 7, "The Individualization of Society,"argues that it is no longer possible to understand, through traditional social scientific reasoning, collective aspects of social and economic exclusion. "The long-term unemployed or overextended households are not populations in the traditional sense, nor are they part of a sociological group... Therefore, 'counting' the excluded is no use, for they cannot fit into a category for social action" (p. 98). More generally, "the traditional sociological approach, methodologically linked to intersecting tables of data ... is clearly worn out. ...social historians have also discovered the quantitative approaches to be deadends" (p. 101). Rosanvallon concludes that we can understand the processes of exclusion only as it is experienced by individuals (hence the chapter title), through biography - "restor[ing] to the data their individual values" (p. 102). For a social scientist, this conclusion seems almost irresponsible insofar as it carries the expectation of being taken seriously. There is no difficulty with the claim that the excluded cannot be subsumed under one single type; but Rosanvallon seems not to have considered the possibility that the use of several types can usefully organize our thinking about exclusion. The notion that there are no types at all is puzzling, to say the least. 
Reviews

\title{
References Cited:
}

Finder, Alan.

1998. "Evidence is scant that workfare leads to full-time jobs." New York Times, April 12:A1.

Mink, Gwendolyn.

1998. Welfare's End. Ithaca: Cornell University Press.

Piven, Frances Fox and Richard A. Cloward.

1993. Regulating the Poor: The Functions of Public Welfare. New York: Vintage.

\section{Without a Map: Political Tactics and Economic Reform in Russia, by Andrei Shleifer and Daniel Treisman, Cambridge, MA: MIT Press (2000), 223 pp.}

\author{
Reviewed by Marshall I. Goldman, Davis Professor of Russian Economics, Emeritus, \\ Wellesley College, Associate Director, Davis Center for Russian Studies, Harvard \\ University.
}

\begin{abstract}
After almost a decade of trying to transit from central planning to markets, analysts are now beginning to examine what went right or wrong, and why. Such studies are particularly interesting when their authors were among those providing guidance in the early days of the reforms. In Without a Map: Political Tactics and Economic Reform in Russia, Andrei Shleifer, the winner of the John Bates Clark Medal in Economics, joins with Daniel Treisman, an Assistant Professor of Political Science at UCLA, to evaluate the success of privatization, macro stabilization, and tax reform in Russia. Shleifer was one of the chief advisors to the Russian privatization chief Anatoly Chubais, and also a consultant in Russia's battle with inflation and macro stabilization. One half of the book is great, but, surprise, surprise, they find that while privatization and macro stabilization were successful, tax reform, which Shleifer did not work on, was not.

The most innovative part of the study is their approach. Rather than concern themselves with "when" the reform went into effect, they devote themselves instead to the more intriguing and challenging question of "how". Looking back at what happened, they ask "how" it succeeded and, in the case of tax reform, "how" it failed. They focus on what they classify as "stakeholders" and what was done to induce them to support, rather than oppose, desirable reforms. In this way, they propose future strategies for overcoming opposition. By framing the challenge in such a manner, future reformers are more likely to consider how coalitions will be formed which will support rather than oppose the changes they seek. So far so good. Shleifer and Treisman argue from experience that the reforms involve much more than searching for designs; what is also needed, they suggest, is a touch of Albert Hirschman and Niccolo Machiavelli.

It is when they begin to examine their own handiwork, particularly Shleifer's, that the authors lose their credibility. Thus, while they spend considerable time on how to create a coalition of supportive stakeholders that will outmaneuver opposing stakeholders, they barely acknowledge that many, if not all, of the obstructive stakeholders had become stakeholders because of the early but misguided privatization efforts (there is one scant acknowledgment that this might have occurred on p. 17). Concretely, the privatization policies that were so proudly designed were largely responsible for giving birth to the oligarchs, who then did all they could to thwart other efforts to pass effective tax legislation.

Their praise for the privatization program is the most serious shortcoming of their argument. Chubais has acknowledged that he moved rapidly with privatization more for political than economic reasons. He was worried that the communists and their supporters might seek to reinstate a communist system. The best antidote to such an effort was to take the country's businesses and industries out of state control and put ownership into the hands of private individuals. By providing individuals with ownership shares or vouchers (a form of people's capitalism), Chubais argued that he could then create a force that would resist any effort to return to the ways of the past. Shleifer and his fellow advisors designed the voucher system and some of the privatization variants offered to the factory workers and managers.

To be fair, neither Chubais nor Shleifer expected that their policies would lead to so many factory managers becoming owners, or to the birth of the oligarchs. Yegor Gaidar, the chief architect of the overall economic reforms,
\end{abstract}

